\title{
Multicultural Competence and Cosmopolitan Citizenship in the Hispanic-Japanese Context of Higher Education
}

\author{
Emilio José Delgado-Algarra ${ }^{1} \odot$, César Bernal-Bravo ${ }^{2} \odot$ and Eloy López-Meneses ${ }^{3} \odot$ \\ ${ }^{1}$ Department of Integrated Didactics, University of Huelva, Spain \\ ${ }^{2}$ Department of Education Sciences, Language, Culture and Arts, Rey Juan Carlos University, Spain \\ ${ }^{3}$ Department of Education and Social Psychology, Pablo de Olavide University, Spain
}

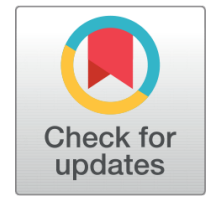

Received 11-03-2019

Revised 18-03-2019

Accepted 01-04-2019

Published 15-07-2019

\section{Corresponding Author}

Emilio José Delgado-Algarra,

emilio.delgado@ddcc.uhu.es

Facultad de Educación,

Psicología y Ciencias del

Deporte Universidad de Huelva

Avda. de las Fuerzas Armadas

SN (CP 21007), Huelva, Spain

DOI https://doi.org/10.7821/

naer.2019.7.425

Pages: 166-183

Distributed under

Creative Commons CC BY 4.0

Copyright: (C) NAER Journal of New Approaches in Educational Research 2019

\section{OPEN ACCESS}

\section{ABSTRACT}

The increase in the internationalization of universities has been accompanied by an increase in multiculturalism in classrooms. Due to this situation, with the objective of knowing the conceptions of university professors around pluricultural competence and attending to the connection with their positioning in relation to the models of cosmopolitan citizenship; a mixed research is developed in the Hispanic-Japanese context of higher education, focusing attention on education and social sciences professors. In general, it is concluded that there are connections between the positioning of multiculturalism and cosmopolitan citizenship. Thus, the university professors of both countries highlight the advantages of cultural plurality in educational environments and, despite the fact that there is governmental support for academic internationalization, in the sample of Japanese professors, there is a greater concern about the preservation of national identity in cultural plurality.

Keywords TEACHING ATTITUDE, HIGHER EDUCATION, MULTICULTURALISM, NATIONALITY, COMPARATIVE ANALYSIS

\section{INTRODUCTION: TOWARDS A DEFINITION OF GLOBAL CITIZENSHIP}

Migratory movements and globalization have contributed to the increase of cultural plurality and the construction of hybrid identities. As indicated by Carretero (2011), the compatibilization of identities generated in close socialization environments or derived from ethnicity, culture, religion or language, in some cases, have led to cultural wars and identity conflicts.

The conceptualization of citizenship depends on ideological positions. In this way, as indicated by Carretero (2011); Maiztegui (2008), since the 1980s, the debate on citizenship and, later, citizenship education has intensified in the media, international organizations, public institutions and universities. 
On the other hand, classifications and typologies have been multiple. The liberal conception of citizenship focusses on civil rights (freedom, the right to own property and the right to justice), political rights (right to participate in the public sphere) and social rights (right to a full life) of each citizen, with a great influence of "citizenship and social class" Marshall (1949). Represented by Habermas, Skinner, Pettit, Pocock, etc., republican citizenship emphasizes citizen participation and responsibilities. Communitarian citizenship claims the concept of community, loyalty and national identity, and this is represented by authors such as Walzer, MacIntyre, Taylor, Sander or Miller. Radical citizenship, linked to the radical democracy model Mouffe (2017), highlights the importance of ideological positions, vindication and conflict.

In short, there is no universally accepted definition of citizenship; however, from an eclectic approach, we could define it as:

legal status that integrates the knowledge and exercise of rights, and the assumption of responsibility that materializes through active and critical participation in the different spheres that make up the current world (society, economy, culture and politics); being able to transcend from the local to the global, marked by the exercise of individual responsibilities, rights and liberties without limiting the rights of other citizens; because, in essence, all citizens who assume responsible citizenship understand that equality, dialogue, rejection of situations of social injustice and, in general, respect for Human Rights must be demanded in any democratic State(Delgado-Algarra, 2015, p. II).

On the other hand, from the aforementioned eclectic perspective and highlighting the relevance of some aspects of radical democracy, Delgado-Algarra and Estepa-Giménez consider that a good citizen is:

able to analyze critically the interactions that occur in their environment, so that, knowing their rights and duties, is able to act coherently, in a competent manner and within an ethical framework, in order to carry out actions in the social, political, economic and cultural fields; allowing functional self-development within socio-economic structures not considered definitive (Delgado-Algarra and Estepa-Giménez, 2018, p. 367).

In this case, we focus on the model of cosmopolitan citizenship or civic cosmopolitanism, a model represented by Held and Cortina; focuses on the defense of a system of universal rights and responsibilities (Delgado-Algarra \& Estepa, 2017).

Every four years, UNESCO (2018) receives information from the Member States on the measures adopted to implement the 1974 Recommendation in the different levels of education from early childhood to university education. In "Findings of the 6th Consultation on the implementation of the 1974 Recommendation concerning Education for International Understanding, Co-operation and Peace and Education relating to Human Rights and Fundamental Freedoms (2012-2016)", it is emphasized that the key principles of 1974 
are included in the educational policy of most countries; also including curricula. However, less attention to cultural diversity and tolerance has been observed.

In general, $88 \%$ of the countries (72 in total) adopt a teaching curriculum with the principles of 74 from a cross-cutting approach. In cases in which they opt for separate subjects, these subjects are civic / citizenship education, social studies and history. On the other hand, the transversally in the teaching of these principles reaches a value of $85 \%$ in 14 countries in Asia and the Pacific and 88\% in 35 countries in Europe and North America.

Finally, although the didactic approaches focused on the students are the most popular and political predisposition has been registered to prioritize issues related to multiculturalism, the insufficient teacher training and the lack of resources that accompany the initiatives are two important problems. To understand the urgency of the situation, we must go back twenty years, when UNESCO (1998), through the report "Citizen Education for the XXI Century", had already echoed that the growth of migratory movements was leading professors to attend to a growing number of students from different cultural backgrounds. In addition, in that report, teacher training in the field of education in environments of cultural plurality was proposed as a new form of action against racism in the classroom.

\section{PLURILINGUAL SOCIAL ACTORS AND PARTIAL COMMUNICATIVE COMPETENCES}

With special importance on the social actor who communicates with competence, more or less, in several languages and in relation to various cultures, the notion of "plurilingual social actor" includes both plurilingual competence (dynamic and developing linguistic repertoire), as well as pluricultural competence (coexistence of different languages at the social level); defining the ability to communicate effectively in particular situations (Coste \& Simon, 2009). In other words, taking the Common European Framework of Reference for Languages as a reference, plurilingualism and pluriculturalism:

exploits pre-existing sociolinguistic and pragmatic competences which in turn develops them further; leads to a better perception of what is general and what is specific concerning the linguistic organisation of different languages (form of metalinguistic, interlinguistic or so to speak 'hyperlinguistic' awareness); by its nature refines knowledge of how to learn and the capacity to enter into relations with others and new situations. (2018, p. 134)

Due to the complexity of social interactions, overlap and juxtaposition turns out to be an insufficient variable to assess the communicative competence of a social actor. Plurilingual and pluricultural competence is presented as unbalanced or unequal. In this sense, as indicated by Coste, Moore, and Zarate (2009), the imbalance in both competences is due to aptitude in relation to the language, which can vary, and there may be imbalances in basic skills or imbalances between the plurilingual and pluricultural profile.

The imbalances in both competences mean a variation in the strategies that compensate for the communicative limitations of the actor with other interlocutors, strategies such as 
the use of gestures, mime, proxemics, etc. or even the rethinking of the message (DelgadoAlgarra, 2017). In other words, by recognizing partial competence, an imperfect mastery of the foreign language and of plurilingual competence is recognized in certain socio-cultural contexts.

On the other hand, as indicated by Toledo, Rubio, and Hermosín (2012), there are 3 types of plurilingualism:

- The curricula in other languages begin with some subjects in foreign language, increasing the number of credits in the following courses until more than $50 \%$ of the degree can be studied in another language.

- The student can choose between studying his degree entirely in the official language of the country or with a foreign language.

- The students have the possibility of studying in a foreign university through collaboration agreements so that they can study some of their subjects or carry out professional practical modules.

The development of both competences, as highlighted by Gajo (2014)and Delgado-Algarra (2017); Ikeno (2011), provides linguistic awareness tools and metacognitive strategies that, from a holistic perspective and in interaction with social sciences education, promote the ability to use the language for communication and intercultural participation in situations where the social actor acquires great importance.

\section{ACADEMIC INTERNATIONALIZATION IN THE HISPANIC-JAPANESE CONTEXT}

As in the other democratic countries, academic internationalization and civic competence in plurilingual and pluricultural contexts become a fundamental axis of educational policies in Spain and Japan. In the Spanish context, the report "Strategist for the Internationalization of Spanish Universities" (2015-2020) of the Ministry of Education, Culture and Sports prepared by the Internationalization of Universities Working Group (MEC, 2014) is noteworthy. In this report, besides the increase of the international attraction of the universities and the promotion of the international competitiveness of the environment, it includes the proposal of other actions related to the establishment and consolidation of an internationalized university system and the intensification of cooperation in higher education with other universities in the world. In relation to the internationalized university system, actions such as training and the provision of skills to work in an open international environment or the increase and measurement of the mobility of students, research teaching staff and administration and services personnel are considered. Continuing with this report, cooperation in higher education was supported by the promotion of cooperation with university systems in the European Union and other countries, including East Asian countries; highlighting that Spanish universities should be more present in the implementation of Bilateral Agreements that the European Union has signed with countries such as the United States, Canada and other industrialized countries such as Australia, New Zealand, Japan and South 
Korea.Rumbley and Rumbley and Howard (2015), in their study of the European Parliament Internationalization of Higher Education, highlight the fact that since the entry of Spain into the European Union in 1986, the European context has been a factor of great relevance for the development of policies and national strategies for the promotion of academic internationalization. As an example of this, Spain is one of the countries that sends and receives more Erasmus students, without forgetting its involvement in the European Research Programs and the Bologna Process De Wit, Rumbley, and Vélez (2017).

In the Japanese context, as indicated by Ikeno (2011), post-war educational policies can be divided into 4 major phases: without principles or policies (1945-1947), oriented to experience (1947-1955), oriented towards knowledge (1955-1989) and activity-oriented (1989-present). Within this last phase, the changes in educational policies were driven in response to a series of educational, economic and social problems that Japan experienced in the 1990s. As a consequence, the Commission of the Prime Minister on the Objectives of Japan in the 21st Century (2000) prepared the report "The Frontier Within: Individual Empowerment and Better Governance in the New Millennium" which concluded that radical educational reform was necessary, boosting interest in openness to academic and social internationalization from politics, paying special attention to Japan's role in the world.

It is also relevant to highlight some concrete internationalization measures such as the "Plan for the promotion of 300,000 international studentsup to 2020" and the Internationalization Project "Global 30" Ministry of Education and MEXT. (2011) or the "Second Basic Plan for the Promotion of Education" (Ministry of Education, Culture, Sports, Science, and Technology. MEXT., 2013) to reconstruct Japanese education based on the principles of the revised Basic Education Law, highlighting the development of social competences where a balance between independence and collaboration is found within a society in a continuous process of transformation. Hammond and Keating (2018), through their research, have shown that in the programs of Japanese universities internationalization strategies have been promoted to maximize global competitiveness. In this way, an adaptation of education for global citizenship is carried out to fit institutional commitments.

In general, in the Spanish-Japanese context, there is a growing openness to civic interaction and linguistic and cultural enrichment, producing a real increase in plurilingual and pluricultural academic environments. In this situation, a piece of research is presented where professorsof education and social sciences of 8 Spanish and Japanese universities collaborate; showing their conceptions about citizenship and the elements that intervene in the development of pluricultural competence in higher education, analyzing the most relevant interactions with the characteristic elements of cosmopolitan citizenship.

\section{RESEARCH DESIGN AND METHODOLOGY}

In general, a mixed research design is presented, a piece of research that starts from positivist and interpretative paradigm attempts to know and understand professors' conceptions of citizenship and plurilingual and pluricultural education in the Hispanic-Japanese context of Higher Education; in addition to the connection between them. Thus, from a flexible 
theoretical approach and with the support of multiple sources, the problems and objectives of the research are defined.

Likewise, starting from the theoretical framework and the revision around the problem, a system of categories is elaborated in three blocks: citizenship, plurilingual competence and pluricultural competence; focusing on the third block with some aspects of the first block. The aforementioned system of categories serves as reference for the configuration of CYASPS questionnaire (Citizenship and Plurilingual Social Actor in Higher Education) and for the systematization of data and information analysis.

\subsection{Problems and objectives}

In this section, the specific research problems and objectives included in this article are presented. Linked to the respective specific research objectives, three specific problems are answered:

- E.P.3:What are the professors' conceptions of citizenship in the Hispanic-Japanese context of Higher Education?

- E.P.5:What are the professors' conceptions of pluricultural education in the HispanicJapanese context of Higher Education?

- E.P.7:How are citizenship and pluriculturality linked in the Hispanic-Japanese context of Higher Education?

The specific objectives (O.E.) in this text will be:

- E.O.3: Know the professors' conceptions of citizenship in the Hispanic-Japanese educational context.

- E.O.5: Know the professors' conceptions of pluricultural education in the HispanicJapanese educational context.

- E.O.7: Understand the link between citizenship and pluricultural education in the Hispanic-Japanese educational context of HigherEducation.

\subsection{Population and sample}

Due to the comparative approach of the research, the population has been constituted by the university teaching staff of education and social sciences from 8 universities:

- Spanish universities: University of Huelva (UHU), Autonomous University of Madrid (UAM) University of Salamanca (USAL), University of Barcelona (UB).

- Japanese universities: Hiroshima University (HID), Sophia University (JD), Waseda University (WD), University of Hokkaido (HOD).

For the configuration of the lists and contact data of the eligible population, both the academic planning reports of the aforementioned universities for the 2017-2018 academic year and the websites of the respective faculties of education and social sciences have been consulted. 
The following aspects have been taken into account to define the sample (Fowler, 2014): the representativeness of the sample framework, the possibility or not, of calculating the probability of selection of each member of the sample and the efficiency or ratio of proportionality of the sample with respect to the population.

In short, it is not intended to generalize the results. This leads to a selection of the representative sample within a population dimension previously carried out. Thus, in relation to the representativeness of the sample framework, first, prior to the statistical calculations, the criterion that the sample size is 5 times higher than the number of Likert scale items of the data collection instrument is taken into account (216 teachers, 40 items). Regarding the probability of selection of each individual and the efficiency or ratio, the proportionality between the reference population and the sample is maintained, reaching the volume of objective sample in the terms that are reflected in Table 1.

\begin{tabular}{llllll}
\hline \multicolumn{2}{l}{ Table 1} & \multicolumn{2}{l}{ Population, sample and probability of selection } & & \\
$\begin{array}{l}\text { Uni- } \\
\text { versity }\end{array}$ & $\begin{array}{l}\text { Popu- } \\
\text { lation }\end{array}$ & $\begin{array}{l}\text { Probability of } \\
\text { selection (1/2) }\end{array}$ & $\begin{array}{l}\text { Probability of } \\
\text { selection }(\mathbf{2} / \mathbf{2})\end{array}$ & $\begin{array}{l}\text { Sample } \\
\text { volume (goal) }\end{array}$ & $\begin{array}{l}\text { Sample } \\
\text { volume (goal) }\end{array}$ \\
\hline UHU & 147 & $100 \%$ & $12,50 \%$ & 19 & 20 \\
UAM & 216 & $100 \%$ & $12,50 \%$ & 27 & 29 \\
USAL & 193 & $100 \%$ & $12,50 \%$ & 25 & 27 \\
UB & 417 & $100 \%$ & $12,50 \%$ & 53 & 56 \\
HID & 156 & $100 \%$ & $12,50 \%$ & 20 & 21 \\
JD & 96 & $100 \%$ & $12,50 \%$ & 12 & 13 \\
WD & 276 & $100 \%$ & $12,50 \%$ & 33 & 35 \\
HOD & 119 & $100 \%$ & $12,50 \%$ & 19 & 16 \\
Total & 1620 & & & 205 & 216 \\
\hline
\end{tabular}

After designing and validating the data collection questionnaire by a multilingual specialist team, Spanish-Japanese, Japanese-English and English-Spanish, CYASPS is distributed extensively to the university professors of the sample.

\subsection{Materials and methods}

The research is ex-post-facto, so the researcher does not have direct control over the variables and there is no modification of the phenomenon or situation under analysis. Within this kind of research, a selection of variables is made and the relationships between them are estimated; focusing, as indicated by Pérez, Cuenca, and Ferreras (2010), in the present in a natural way and relying on statistical and correlational methods that allow us to discover the latent relationships between variables. Finally, opting for an inductive model, a descriptive and factorial analysis is carried out.

The descriptive analysis responds to E.P.3 and E.P.5, taking as reference the frequency and measures of central tendency: mean, mode and median. Then, a factorial analysis that allows a response to E.P.7 is carried out; an analysis where, first, the Bartlett sphericity test and adequacy measurements of the KMO sample are taken into account. KMO has a value ,772 [above ,750], which suggests that a statistical analysis is highly acceptable. We continue 
with the analysis of the correlation matrix, taking into account the Pearson correlation and the coefficient of determination. This is followed by a reduction of factors using the main components method, but for reasons of space, it is not included in this article. The descriptive and factorial analysis is carried out with the support of the statistical analysis program SPSS; obtaining conclusions that will be compared with other conclusions of research during the discussion process.

\subsubsection{Establishing a categories system}

Based on the theoretical framework about the problem, taking specific previous references of Delgado-Algarra (2017) and Delgado-Algarra and Estepa-Giménez (2018), and considering as a general reference texts such as Martín-Cáceres and Cuenca-López (2015), developed within HETEIC R+D project (2016 - 2020), EDU2015-67953-P with funding from the Ministry of Economy and Competitiveness of Spain; a categories system that consists of three blocks is elaborated: citizenship (CIU), plurilingual competence (CPL) and pluricultural competence (CPC). In table 2 , focusing on the aspects analyzed in this article, the indicators and descriptors of the subcategory of cosmopolitan citizenship are presented; while, in table 3, the complete category of pluricultural competence is shown.

Table 2 Categories system. Category: citizenship. Subcategory: cosmopolitan.

\begin{tabular}{llll} 
Category & Subcategory & Indicators & Descriptors \\
\hline Citizenship (CIU) & Cosmopolitan (COS) & $\begin{array}{l}\text { Globalization (glo) } \\
\text { Identity (idn) }\end{array}$ & $\begin{array}{l}\text { Citizenship defined by cultural globalisation [glo] } \\
\text { Does not acknowledge more than one civic identity q1.14, q1.20 } \\
\text { [idn1] } \\
\end{array}$ \\
& $\begin{array}{l}\text { Partially acknowledges the existence of more than one } \\
\text { civic identity [idn2] } \\
\text { Acknowledges the existence of more than one civic } \\
\text { identity [idn3] }\end{array}$ & $\begin{array}{l}\text { Does not adopt consumerist attitudes [csm1] } \\
\text { Consumerism }(\mathrm{csm})\end{array}$ \\
& & $\begin{array}{l}\text { Partially adopts consumerist attitudes [csm2] } \\
\text { Adopts consumerist attitudes [csm3] }\end{array}$ \\
\hline
\end{tabular}

\subsubsection{CYASPS $^{\circledR}$ : instrument for data collection}

For the collection of data, CYASPS questionnaire"Citizenship and Plurilingual Social Actor in Higher Education") is designed and validated. It is sentto 216 professors from Spain and Japan via telematics using Google Forms . CYASPS , trademark M3683892, Classification of Nice number 41 (Education, Training and Cultural Activities) and property of Delgado-Algarra, is a mixed instrument (Likert and short answer) in whose block on citizenship, takes as reference the epistemological sources of CIDIMEN questionnaire "Citizenship and dimensions of Memory", with trademark M3695791 and property of DelgadoAlgarra, López Meneses, Estepa-Giménez and Vázquez-Cano. 
Block 1 "citizenship" consists of 19 Likert-type elements (q1.1-q1.19) and an open response element: "Write 3 key words that, in your opinion, define a good citizen" (q.1.20) In relation to cosmopolitan citizenship, we highlight the following items:

- q1.10- I am committed to sustainable development.

- q1.11- I prefer to pay a little more for products that come from fair trade.

- q1.12- I assume attitudes of rational consumption, solidary and respect with the environment.

- q1.13- I think cultural globalisation is positive.

- q1.14- Citizens can have more than one civic identity.

On the other hand, block 3 "pluricultural competence" consists of 10 Likert-type items and an open response item: "What are the advantages and disadvantages of learning in a pluricultural environment?" (Q.3.11). In relation to the importance that certain aspects have in

Table 3 Categories system. Category: pluricultural competence.

\begin{tabular}{|c|c|c|c|c|}
\hline Category & Subcategory & Indicators & Descriptors & \\
\hline \multirow[t]{21}{*}{$\begin{array}{l}\text { Pluricultural } \\
\text { competence (CPC) }\end{array}$} & $\begin{array}{l}\text { Elements } \\
(\text { EM2) }\end{array}$ & Cultural reference (rcu) & Cultural reference is irrelevant [rcul] & $\begin{array}{l}\mathrm{q} 3.2, \mathrm{q} 3.5, \mathrm{q} 3.6, \\
\mathrm{q} 3.11\end{array}$ \\
\hline & & & Cultural reference is somewhat relevant [rcu2] & \\
\hline & & & Cultural reference is relevant [rcu3] & \\
\hline & & $\begin{array}{l}\text { Academic -professional } \\
\text { (rap) }\end{array}$ & $\begin{array}{l}\text { Academic level and professional experience are not } \\
\text { relevant [rap1] }\end{array}$ & $\mathrm{q} 3.1, \mathrm{q} 3.11$ \\
\hline & & & $\begin{array}{l}\text { Academic level and professional experience are } \\
\text { somewhat relevant [rap2] }\end{array}$ & \\
\hline & & & $\begin{array}{l}\text { Academic level and professional experience are } \\
\text { relevant [rap3] }\end{array}$ & \\
\hline & & Mobility (mov) & Travel experience is irrelevant [movl] & $\mathrm{q} 3.3, \mathrm{q} 3.11$ \\
\hline & & & Travel experience is somewhat relevant [mov2] & \\
\hline & & & Travel experience is relevant [mov3] & \\
\hline & & Reading (lec) & Reading is not relevant $[\operatorname{lec} 1]$ & \\
\hline & & & Reading is somewhat relevant [lec2] & \\
\hline & & & Reading is relevant [lec3] & \\
\hline & $\begin{array}{l}\text { Interaction } \\
\text { (INT) }\end{array}$ & $\begin{array}{l}\text { Interpersonal interaction } \\
\text { (ipe) }\end{array}$ & Interaction with other people is irrelevant [ipe1] & $\begin{array}{l}\text { q3.7, q3.10, } \\
\text { q3.11 }\end{array}$ \\
\hline & & & $\begin{array}{l}\text { Interaction with other people is somewhat relevant } \\
\text { [ipe2] }\end{array}$ & \\
\hline & & & Interaction with other people is relevant [ipe3] & \\
\hline & & $\begin{array}{l}\text { Interaction with new } \\
\text { situations (ins) }\end{array}$ & Interaction with new situations is irrelevant [isi1] & $\begin{array}{l}\text { q3.8, q3.10, } \\
\text { q3.11 }\end{array}$ \\
\hline & & & $\begin{array}{l}\text { Interaction with new situations is somewhat relevant } \\
\text { [isi2] }\end{array}$ & \\
\hline & & & Interaction with new situations is relevant [isi3] & \\
\hline & & $\begin{array}{l}\text { Interaction with problems } \\
\text { (ipr) }\end{array}$ & Problem-solving is not relevant [ipr1] & $\begin{array}{l}\text { q3.9, q3.10, } \\
\text { q3.11 }\end{array}$ \\
\hline & & & Problem-solving is somewhat relevant [ipr2] & \\
\hline & & & Problem-solving is relevant [ipr3] & \\
\hline
\end{tabular}


the development of pluricultural competence, items are:

- q3.1- Academic level and professional experience.

- q3.2- Family background.

- q3.3- Travel experience.

- q3.4- Readings.

- q3.5- Cultural references.

- q3.6- Actions adapted to the cultural background.

- q3.7- Interaction with other people.

- q3.8- Interaction with new situations.

- q3.9- Problem solving.

- q3.10- Contact with other languages.

\section{RESULTS}

In relation to the category "citizenship" and the subcategory "cosmopolitan" (COS), considering the descriptive statistics of central tendency (Table 4), in general, medium-high values are observed; with more high values in the recognition that a citizen can have more than one civic identity (q1.14) with a mean value 4.38 and $\sigma, 826$. According to the responses of the university professors of the sample, the commitment of the teaching staff to sustainable development, fair trade and rational consumption acquires values of moderate agreement, being relatively low and with different values of agreement to consider globalization as a positive process (mean value 3,21 and $\sigma 1,053$ ).

Table 4 Descriptive statistics of central tendency of the block (q1) about citizenship linked to cosmopolitan citizenship.

\begin{tabular}{lllll} 
Item & Mean & Median & Mode & $\sigma$ \\
\hline (q1.10) Sustainable development & 3,86 & 4 & 4 & 1,008 \\
(q1.11) Fair Trade & 3,83 & 4 & 4 & 0,964 \\
(q1.12) Rational consumption & 3,9 & 4 & 4 & 1,05 \\
(q1.13) Positive globalization & 3,21 & 3 & 3 & 1,053 \\
(q1.14) Dual identity & 4,38 & 5 & 5 & 0,826 \\
\hline
\end{tabular}

Focusing on the indicator "identity" (idn), in relation to the item q1.14 "citizen can have more than one civic identity" and attending frequencies, $90.7 \%$ of teachers show high or very high levels of acceptance when considering that a citizen can have more than one civic identity.

Regarding the contingencies (Figure 1), crossing the response of university professors grouped by countries and the item q1.14, it is observed that in the response of professors in the sample of Spanish universities, high and moderate agreement (61/133 and 57/133, respectively) predominates, as is the case with the responses of the sample of professors from Japanese universities, (52/133 and 26/133, respectively). However, within the cosmopolitan 


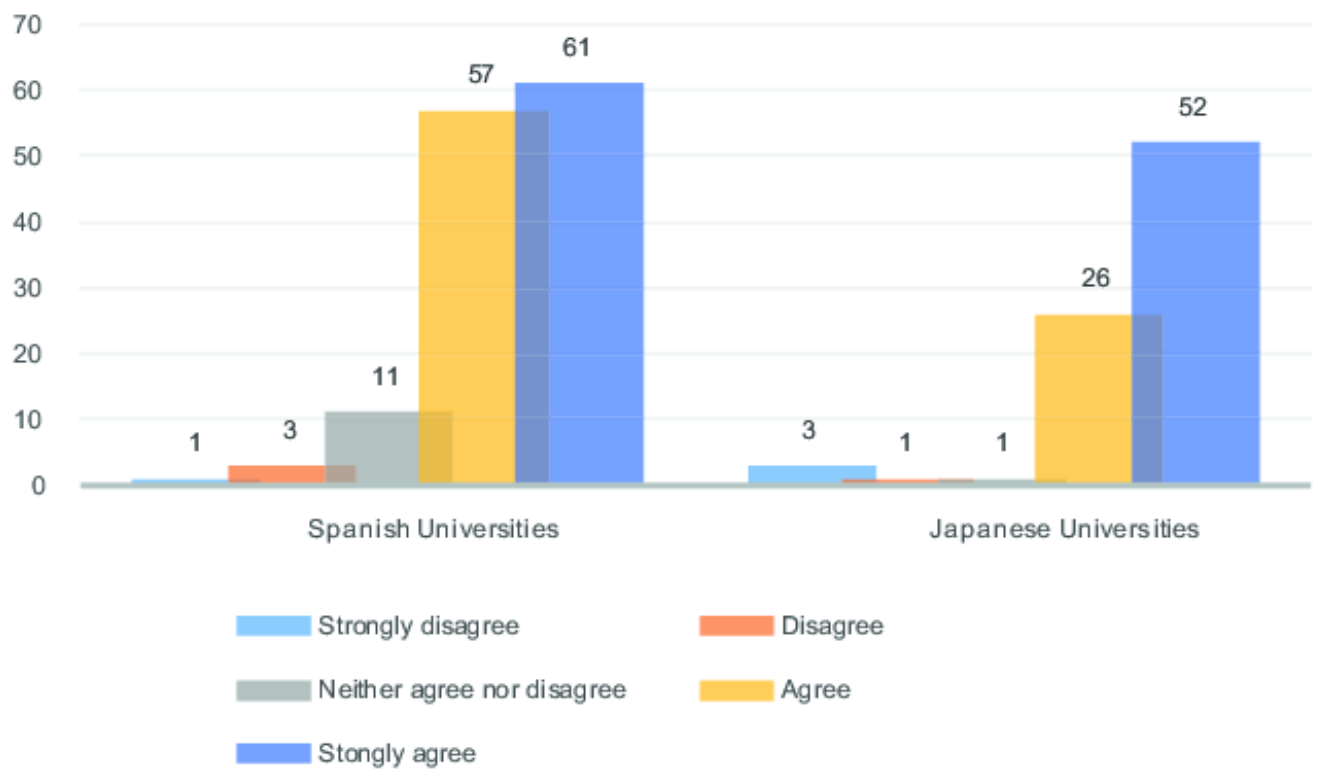

Figure 1 Contingency chart. Country of the universities ${ }^{\star} \mathrm{q} 1.14$.

citizenship, the acceptance that citizens can have more than one identity, is much more pronounced in the case of the faculty sample of Japanese universities.

In relation to the pluricultural competence category, the professors of the sample value the importance that the indicators of the subcategories "elements" (EM2) and "interaction" (INT) have for their development. Taking into account the descriptive statistics of central tendency (Table 5), the medium-high mean values stand out, especially the travel experience elements (q3.3) with a mean value 4.17 and $\sigma, 907$ and reading (q3.4) with a mean value 4.12 and $\sigma, 758$ and the interaction with people (q3.7) with a mean value 4.65 and $\sigma, 674$ and, with a lower value, new situations (q3.8) with a mean value 4.39 and $\sigma, 832$.

Table 5 Descriptive statistics of central tendency of the block (q3) of pluricultural competence.

\begin{tabular}{lllll} 
Item & Mean & Median & Mode & $\sigma$ \\
\hline (q3.1) Academic level / professional experience. & 3,75 & 4 & 4 & 0,942 \\
(q3.2) Family backgroud. & 3,89 & 4 & 4 & 0,872 \\
(q3.3) Travel experience. & 4,17 & 4 & 5 & 0,907 \\
(q3.4) Reading. & 4,12 & 4 & 4 & 0,758 \\
(q3.5) Cultural references. & 4,04 & 4 & 4 & 0,866 \\
(q3.6) Actions adapted to the cultural background. & 3,99 & 4 & 4 & 0,866 \\
(q3.7) Interaction with people. & 4,65 & 5 & 5 & 0,674 \\
(q3.8) Interaction with situations. & 4,39 & 5 & 5 & 0,832 \\
(q3.9) Problem solving & 4,19 & 4 & 4 & 0,785 \\
(q3.10) Contact with other languages. & 4,47 & 5 & 5 & 0,819 \\
\hline
\end{tabular}


The lowest statistical mean values were granted in "academic level and professional experience" (q3.1), mean 3.75, $\sigma$,942, and in "Family background" (q3.2), mean 3.89, $\sigma, 872$. Regarding frequencies, $95.4 \%$ of teachers in the sample indicated high and medium-high values for the importance of travel experience, and $90.2 \%$ in relation to interaction with other people.

Regarding the correlations between the defining aspects of cosmopolitan citizenship and those that contribute to the improvement of pluricultural competence, although there are few high correlations; however, these are highly significant (table 6).

Table 6 Correlation matrix: cosmopolitan citizenship - pluricultural competence.

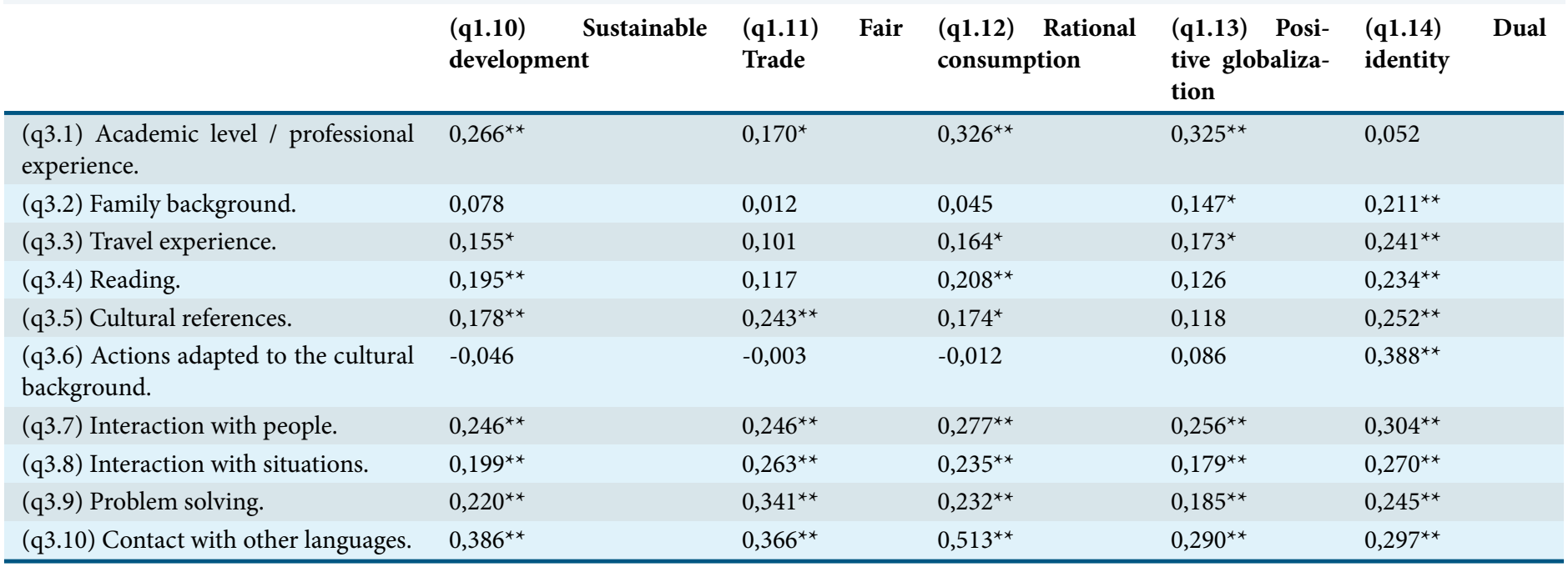

Note: $\left.{ }^{\star} \mathrm{p}<.05 ;{ }^{* *} \mathrm{p}<.01 ; \mathrm{N}=215\right)$

The "identity" (idn) (q1.14) of the "cosmopolitan" citizenship (COS) has a relatively low but significant correlation with the "cultural reference" (rcu) (q3.6) of the "elements" (EM2) $\left(, 388^{* *}\right)$ and another with "interpersonal interaction" (ipe) (q3.7) of the "interaction" (INT) $\left(, 304^{\star *}\right)$ (Figure 2).

In relation to "consumerism" (csm) fair trade (q1.11) has moderate and significant correlations with sustainable development (q1.10) and rational consumption (q1.12). Regarding the correlations of items inter-block citizenship (b1) - pluricultural competence (b3), within the citizenship "cosmopolitan" (COS), consumerism (csm) and, within it, fair trade (q1.11), has a low but significant correlation with the contact with other languages (q3.10) $\left(0,366^{* *}\right)$ and with the interaction with problems (ipr) (q3.9) $\left(0,341^{* *}\right)$ within the indicator "interaction" (INT).

\section{CONCLUSIONS AND DISCUSSION}

Since the 1980s, both in Europe and in Japan, the impulse of global citizenship has met resistance due to the fear that traditional values and morals were lost. However, as regards academic internationalization, there is a growing openness to civic interaction and linguistic and cultural enrichment, with a real increase in plurilingual and pluricultural academic 


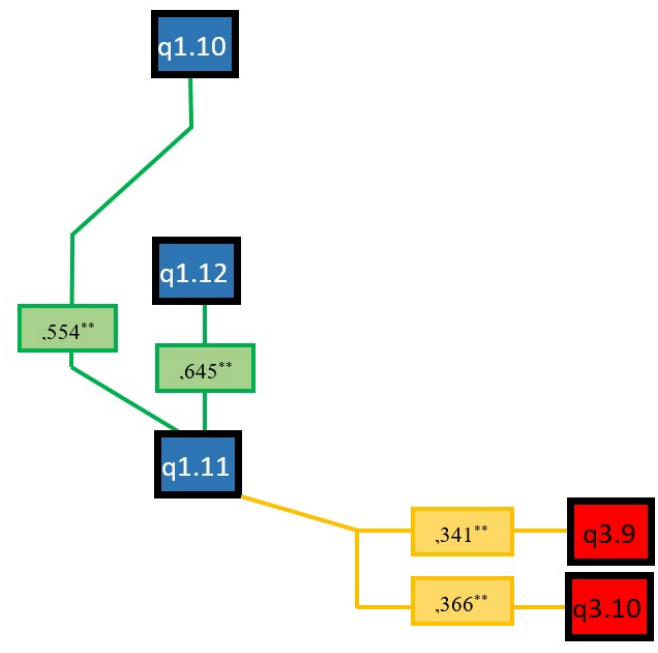

Figure 2 Correlational structure cosmopolitan citizenship (consumerism) - Multicultural competence (interaction).

environments. In the policies of Spain and Japan, the internationalization of higher education, mobility and cooperation among university teaching staff have considerable importance.

Responding to E.P.3 What are the professors' conceptions of citizenship in the HispanicJapanese context of Higher Education?, Despite the fact that, in our study, both the teaching staff of the sample of Spain and Japan recognize more than one civic identity and although teacher training on education in environments of cultural plurality was raised by UNESCO (1998) as a new form of action against racism two decades ago; our conclusions are different from the conclusions of the qualitative study of Estrellés and Romero (2016) with 29 Spanish professors.

In this sense, in addition to the recognition of exploratory statistics and central tendency on aspects of cosmopolitan citizenship, in our study, when defining a good citizen we find that some of the most outstanding terms are solidarity (26 teachers), responsibility (25 teachers), commitment (15 teachers) or respect (14 teachers); However, in the other study, throughout the interviews to define citizen education, no references were made to aspects of civic cosmopolitanism, multiculturalism or interculturality.

This situation could indicate that increasing the volume of the sample is more likely to receive the response from professors who value issues related to global citizenship. It can also be concluded that, despite the data sent by the member states (2012-2016), they indicate that the key principles of 1974 are included in the education policy and in the curricula of most countries (UNESCO, 2018), this does not necessarily mean a change in the teaching positions, among other aspects, in terms of the importance they give to issues related to civic cosmopolitanism.

In line with our research conclussions, the European Euridyce report argues that "Citizenship education is one of the principal means by which European countries help young 
people acquire the social and civic competences they will need in their future lives" (EURYDICE, 2012, p.97); and independently of the trend adopted (independent subject, in some subjects or by general competences that permeate all the subjects), the report groups the objectives in 4 blocks:

- Development of the political culture: posed as knowledge of the basic facts and the understanding of the key concepts. Some countries include issues such as knowledge of political institutions, cultural heritage, human rights or citizens' rights and responsibilities.

- Acquisition of critical thinking and the ability to analyze: in some countries it includes the knowledge and analysis of information on social and political issues considered relevant.

- Development of values, attitudes and behaviors: related to respect, tolerance and solidarity and where content such as respect for cultural plurality or gender equality can be considered.

- Encouragement of active participation, commitment in the school and the community: with a practical approach to intervention and transformation of the community.

In essence, in addition to the increase in the discourse of global citizenship, which is also reflected in the results of our research, educational and cooperation policies have promoted the importance of educating for global citizenship. This priority has been evidenced when reviewing the objectives and goals of the 2030 Agenda; the participation of Spain in the definition of the new 17 Sustainable Development Goals being particularly significant. Thus, Spain has built a position that prioritizes issues such as the eradication of poverty, the reduction of inequalities, sustainability in all its dimensions or the Human Rights-based approach, (the person, as a subject of rights) AECID. (2015).

In relation to the E.P.5 What are the professors ' conceptions of pluricultural education in the Hispanic-Japanese context of Higher Education?, in the open responses of the Japanese sample of professor in our study (q3.11), 8 of them cited pluricultural conflicts and the loss of identity as a disadvantage of pluricultural educational spaces. So, for example, one professor indicated that "the disadvantage is that the awareness of being Japanese becomes weaker" (q3.11-19). We find important convergences with the results of Chiu (2017) in the Japanese context. In the aforementioned study, it is concluded that, although teachers understand the importance of global citizenship, there are resistances derived from the fear of losing national identity in educational environments of cultural plurality.

It should also be noted that teachers gave significant importance to interaction as a key aspect for the construction of pluricultural competence, especially interaction with other people. In this sense, the study by Cushner, McClelland, and Stafford (2015) concluded that interaction between individuals and groups contributes to efficiently anticipating and dealing with the problems that may arise in intercultural interaction; highlighting the following agents of socialization and cultural transmission: family, school, religious community, neighbors, peer group, digital and printed media, sports, arts, workplace and technology. 
In the complementary volume of the CEFR with new descriptors, it is indicated that facilitating the pluricultural space"reflects the notion of creating a shared space between and among linguistically and culturally different interlocutors" Council of Europe (2018). In line with this report, in our study, the teachers' responses to the sample indicate that personal interaction acquires a significant importance when developing multicultural competence.

The study by Bermingham and O'Rourke (2018) concludes that immigration in Spain has increased the number of multicultural educational spaces and that multilingual environments contribute to increasing multicultural recognition. In other words, in line with the conclusions of our study, personal interaction again appears as a determining factor in the development of pluricultural competence, and we must add that the responses of the faculty of the sample of our research give less importance to the academic level and family background. When developing pluricultural competence, this approach implies giving greater relevance to interactive issues based on communicative action ahead of issues such as family background or level of studies.

E.P.7: "How are citizenship and pluriculturality linked in the Hispanic-Japanese context of Higher Education?", the results of Cuga (2018) show that civic education as a vehicle of multicultural education contributes to the construction of democratic, participatory and responsible citizens, capable of living with the world, with diversity, mutual respect and their own identity and the identity of others. These conclusions converge with those of our study where there is a significant correlation between the recognition of identity plurality (the defining element of cosmopolitan citizenship) and the cultural reference or interpersonal interaction as an element of pluricultural competence and as an interactive factor for the construction of pluricultural competence, respectively.

Despite the increase of academic internationalization by the governments of many countries, including Spain and Japan, the review by Martín-Cabello (2017) has concluded that national identity has much greater relevance than global identity and that it is developing a banal cosmopolitanism under the influence of mass media. This is especially convergent with the data analysis of the Japanese sample where, although the MEXT promotes academic internationalization, there is a certain concern on a part of professors for the loss of national identity in educational contexts of cultural plurality. It should be noted that, following the reports provided by the different countries, UNESCO (2018) concludes that the lack of teacher training to manage educational situations of cultural plurality is a major problem. In other words, there is a mismatch between what is raised from politics, the perception of professors and their own training in relation to pluriculturalism.

In short, retaking the definition of citizenship of Delgado-Algarra (2015), if we position ourselves in favor of a model of citizenship where rights and responsibilities are used through the active and critical participation of citizens; It is coherent to conceive a good citizen as one who, knowing their rights and duties, tries to make his civic actions as efficient as possible within our system, allowing the evolution and improvement of it..

Thus, taking into account the above, in a context of pluricultural education, good citizens must know their resources and manage them from an ethical framework; a framework that conditions their decision-making, in a way that facilitates a better functioning of their reality 
in different areas, including the cultural sphere. For this reason, given the importance of the teaching staff and their training, in addition to the awareness of their own conceptions and positions, we highlight the need to propose educational actions, according to which, the students become familiar with ways of participating in their environment, in the field social, economic or political, maintaining a balance between adaptation to society and vindication of their culture and values.

\section{STUDY LIMITATIONS AND FUTURE RESEARCH LINES}

Regarding the limitations of this research, although given the criteria of sample adequacy, the results can be considered valid and reliable; The results and conclusions of the research can not (nor pretend) be extrapolated to all Spanish and Japanese universities. In terms of quantitative analysis, the most complex has been to establish correlational structures, because it was necessary to create criteria that were constant.

At the end of this investigation, other questions are opened and future research lines are raised, questions that can not be solved in the same case and with the same group, but can be studied in other contexts. For example, regarding the question, what are the relations between citizenship and pluricultural competence in the Hispanic - Japanese context of higher education? The number of universities in that context could be expanded or include other countries such as the United States. Equally, another of the questions that have arisen are: how are citizens educated and how are they educated for participation in the Japanese Hispanic context of higher education? These issues have arisen throughout the present work; however, having reached the proposed objectives, this investigation is considered completed.

\section{REFERENCES}

AECID. (2015). La Cooperación Española, preparada para asumir el reto de la Agenda 2030. Retrieved from http://www.aecid.es/EN/Paginas/Sala\%20de\%20Prensa/Noticias/2015/2015 _09/RetoAgenda2030.aspx

Bermingham, N., \& O'Rourke, B. (2018). Language awareness amongst "new speakers" in a multilingual classroom (C. Hélot, C. Frijns, \& K. V. Gorp, Eds.). Boston: Walter de Gruyter Inc. https://doi.org/10.1515/9781501501326-005

Carretero, M. (2011). Teaching history and memories in global worlds. Constructing patriotism. North Carolina: Information Age Publishing.

Chiu, D. Y. (2017). Conceptualizing global citizenship at japanese secondary schools: a case study on the super global high school program (Doctoral dissertation, University of Tokyo, Tokyo). Retrieved from https://repository.dl.itc.u-tokyo.ac.jp/ ?active_action=repository_view_main_item_snippet\&page_id=28\&block_id=31\&index $\_\mathrm{id}=482 \& \mathrm{pn}=1 \& \mathrm{count}=20$ \&order $=11$ \&lang=english

Coste, D., Moore, D., \& Zarate, G. (2009). Plurilingual and pluricultural competence - studies towards a Common European Framework of reference for language learning and teaching. Strasbourg: Council of Europe.

Coste, D., \& Simon, D. L. (2009). The plurilingual social actor. Language, citizenship, edu- 
cation. International Journal of Multilingualism, 6(2), 168-185. https://doi.org/10.1080/ 14790710902846723

Council of Europe. (2018). The CEFR companion volume with new descriptors: Uses and implications for language testing and assessment. Retrieved from https://rm.coe.int/cefr-companion -volume-with-new-descriptors-2018/1680787989

Cuga, C. (2018). Civic Education as vehicle of multicultural education in building democratic citizen. Advances in Social Science, Education and Humanities Research, 251, 160-167. https:// doi.org/10.2991/acec-18.2018.40

Cushner, K. H., McClelland, A., \& Stafford, P. (2015). Human in education. An intercultural approach. New York: Mc Graw Hill Education.

Delgado-Algarra, E. J. (2015). Conocimiento glocal y pensamiento crítico en la educación del Siglo XXI. International Journal of Educational Research and Innovation (IJERI), 4(I-V). Retrieved from https://www.upo.es/revistas/index.php/IJERI/article/view/1452

Delgado-Algarra, E. J. (2017). Actor social plurilingüe como puente entre la enseñanza de las ciencias sociales y las lenguas extranjeras: presentación de la metodología de investigación. International Journal of Educational Research and Innovation (IJERI), 8, 97-107. Retrieved from https://www.upo.es/revistas/index.php/IJERI/article/view/2025

Delgado-Algarra, E. J., \& Estepa, J. (2017). Citizenship education and dimensions of memory in the teaching of social education: research on thinking of secondary education teachers in Huelva and its province. Educación XX1, 20(2), 259-278. https://doi.org/10.5944/educxx1.19041

Delgado-Algarra, E. J., \& Estepa-Giménez, J. (2018). Ciudadanía y dimensiones de la memoria en el aprendizaje de la Historia: análisis de un caso de Educación Secundaria. Vínculos de Historia, 7, 366-388. Retrieved from http://vinculosdehistoria.com/index.php/vinculos/article/view/ vdh_2018.07.20/pdf

De Wit, H., Rumbley, L. E., \& Vélez, J. (2017). Internacionalización de la educación superior española en perspectiva global. In A. Pérez-Encinas, L. Howard, L. E. Rumbey, \& H. De Wit (Eds.), Internacionalización de la Educación Superior en España (pp. 54-69). Madrid: Servicio Español para la Internacionalización de la Educación (SEPIE). https://doi.org/10.14482/ esal.2.10151

Estrellés, M., \& Romero, J. (2016). Teacher education for citizenship in a globalized world: A case study in Spain. Journal of International Social Studies, 6(2), 21-33. Retrieved from https:// files.eric.ed.gov/fulltext/EJ1149364.pdf

EURYDICE. (2012). Citizenship Education in Europe. Bruselas: Education, Audiovisual and Culture Executive Agency. .Disponible en. Retrieved from https://publications.europa.eu/en/ publication-detail/-/publication/ecd20d86-e56b-4635-976c-b103d49cc46c/language-es

Fowler, F. J. (2014). Survey research methods (Edition 5). United Kingdom: SAGE.

Gajo, L. (2014). From normalization to didactization of multilingualism: European and francophone research at the crossroads between linguistics and didactics. In J. Conteh \& G. Meier (Eds.), The multilingual turn in languages education: Opportunities and challenges (pp. 117-135). UK: Multilingual Matters. https://doi.org/10.21832/9781783092246-011

Hammond, C. D., \& Keating, A. (2018). Global citizens or global workers? Comparing university programmes for global citizenship education in Japan and the UK. Compare: A Journal of Comparative and International Education, 48, 915-934. https://doi.org/10.1080/ 03057925.2017.1369393

Ikeno, N. (2011). Postwar citizenship education policy and its development. . In N. Ikeno (Ed.), Citizenship Education in Japan (pp. 15-27). London: Continuum International Publishing Group. https://doi.org/10.5040/9781350091276.ch-002

Maiztegui, C. (2008). Ciudadanía y educación: de la teoría a la práctica. Bilbao: Universidad de 
Deusto.

Marshall, T. H. (1949). Citizenship and social class. Cambridge: Cambridge University Press.

Martín-Cabello, A. (2017). Ciudadanía global. Un studio sobre las identidades sociopolíticas en un mundo interconectado. Arbor, 193(786), 422-. https://doi.org/10.3989/arbor.2017.786n4010

Martín-Cáceres, M., \& Cuenca-López, J. M. (2015). Educomunicación del patrimonio. Educatio Siglo XXI, 33(1), 33-53. https://doi.org/10.6018/j/222491

MEC [Ministerio de Educación, Cultura y Deporte]. (2014). Estrategia para la Internacionalización de las universidades españolas 2015-2020. Retrieved from http://www.educacionyfp.gob.es/ educacion-mecd/dms/mecd/educacion-mecd/areas-educacion/universidades/politica -internacional/estrategia-internacionalizacion/EstrategiaInternacionalizaci-n-Final.pdf

Ministry of Education, Culture, Sports, Science, and Technology. MEXT. (2013). The second basic plan for the promotion of education. Retrieved from http://www.mext.go.jp/en/policy/ education/lawandplan/title01/detail01/1373796.htm

Ministry of Education, S. S., Culture, \& MEXT., T. (2011). Retrieved from www.mext.go.jp/ component/english/_icsFiles/afieldfile/2011/03/07/1303008_003.pdf Progress on.

Mouffe, C. (2017). ¿Cuál es el futuro de la democracia en un período pospolítico? In R. C. CuencaJiménez, D. Allen-Perkins, \& W. F. Gadea (Eds.), Hacia una (re)conceptualización de la democracia contemporánea (pp. 13-24). Sevilla: Fénix Editorial.

Pérez, R. J., Cuenca, J. M., \& Ferreras, M. (2010). Heritage education: Exploring the conceptions of teachers and administrators from the perspective of experimental and social science teaching. Teaching and Teacher Education, 26, 1319-1331. http://doi.org/10.1016/j.tate.2010.01.005

Rumbley, L. E., \& Howard, L. (2015). España. . In H. de Wit, F. Hunter, E. Egron-Polak, \& L. Howard (Eds.), Internationalisation of Higher Education (pp. 167-176). Bruselas: Parlamento Europeo.

The Prime Minister's Commission on Japan's Goals in the 21st Century. (2000). The frontier within: Individual empowerment and better governance in the new millennium (and others, Ed.). Tokyo: Office for the Prime Minister's Commission on Japan's. Retrieved from https://www.kantei.go.jp/jp/21century/report/pdfs/index.html

Toledo, I., Rubio, F. D., \& Hermosín, M. (2012). Creencias, rendimiento académico y actitudes de alumnos universitarios principiantes en un programa plurilingüe. Porta Linguarum: Revista Internacional de Didáctica de las Lenguas. Extranjeras, 18, 213-228.

UNESCO. (1998). Citizenship education for the 21st century. Retrieved from http://www.unesco.org/ education/tlsf/mods/theme_b/interact/mod07task03/appendix.htm

UNESCO. (2018). UNESCO's progress report on education for sustainable development and global citizenship education. Retrieved from https://unesdoc.unesco.org/ark:/48223/pf0000266176 